\title{
Paraneoplastic neuronal intermediate filament autoimmunity
}

Eati Basal, PhD, Nicholas Zalewski, MD, Thomas J. Kryzer, AS, Shannon R. Hinson, PhD, Yong Guo, MD, PhD, Divyanshu Dubey, MD, Eduardo E. Benarroch, MD, Claudia F. Lucchinetti, MD, Sean J. Pittock, MD,

Vanda A. Lennon, MD, PhD, and Andrew McKeon, MD

Neurology ${ }^{\circledR}$ 2018;91:e1677-e1689. doi:10.1212/WNL.0000000000006435

\section{Abstract}

\section{Objective}

To describe paraneoplastic neuronal intermediate filament (NIF) autoimmunity.

\section{Methods}

Archived patient and control serum and CSF specimens were evaluated by tissue-based indirect immunofluorescence assay (IFA). Autoantigens were identified by Western blot and mass spectrometry. NIF specificity was confirmed by dual tissue section staining and 5 recombinant NIF-specific HEK293 cell-based assays (CBAs, for $\alpha$-internexin, neurofilament light [NfL], neurofilament medium, or neurofilament heavy chain, and peripherin). NIF-immunoglobulin Gs (IgGs) were correlated with neurologic syndromes and cancers.

\section{Results}

Among 65 patients, NIF-IgG-positive by IFA and CBAs, 33 were female (51\%). Median symptom onset age was 62 years (range 18-88). Patients fell into 2 groups, defined by the presence of NfL-IgG (21 patients, who mostly had $\geq 4$ NIF-IgGs detected) or its absence (44 patients, who mostly had $\leq 2$ NIF-IgGs detected). Among NfL-IgG-positive patients, 19/21 had $\geq 1$ subacute onset CNS disorders: cerebellar ataxia (11), encephalopathy (11), or myelopathy (2). Cancers were detected in 16 of 21 patients (77\%): carcinomas of neuroendocrine lineage (10) being most common (small cell [5], Merkel cell [3], other neuroendocrine [2]). Two of 257 controls ( $0.8 \%$, both with small cell carcinoma) were positive by both IFA and CBA. Five of 7 patients with immunotherapy data improved. By comparison, the 44 NfL-IgG-negative patients had findings of unclear significance: diverse nervous system disorders $(p=0.006)$, as well as limited $(p=0.003)$ and more diverse $(p<0.0001)$ cancer accompaniments.

\section{Conclusions}

NIF-IgG detection by IFA, with confirmatory CBA testing that yields a profile including NfLIgG, defines a paraneoplastic CNS disorder (usually ataxia or encephalopathy) accompanying neuroendocrine lineage neoplasia.

\author{
Correspondence \\ Dr. McKeon \\ mckeon.andrew@mayo.edu
}

\section{MORE ONLINE}

- CME Course

NPub.org/cmelist 


\section{Glossary}

$\alpha \mathrm{IN}=\alpha$ internexin; $\mathbf{A L S}=$ amyotrophic lateral sclerosis; $\mathbf{C B A}=$ cell-based assay; $\mathbf{C J D}=$ Creutzfeldt-Jakob disease; GFAP = glial fibrillary acidic protein; IFA = immunofluorescence assay; IgG = immunoglobulin G; $\mathbf{M S}=$ multiple sclerosis; $\mathbf{N f H}=$ neurofilament heavy chain; $\mathbf{N f L}=$ neurofilament light chain; $\mathbf{N f M}=$ neurofilament medium chain; $\mathbf{N I F}=$ neuronal intermediate filament; PBS = phosphate-buffered saline.

Paraneoplastic neurologic disorders are initiated as an immune response directed against one or more tumor-expressed neural autoantigens. ${ }^{1}$ Certain neural immunoglobulin G (IgG) paraneoplastic autoantibodies are disease-specific diagnostic biomarkers. Some antibodies likely have pathogenicity derived from events downstream of IgG binding to the extracellular domain of a neural protein (such as the GluN1 subunit of the NMDA receptor). ${ }^{2}$ Other antibodies, such as anti-Hu or anti-Yo, which are reactive with nuclear or cytoplasmic antigens, despite not being pathogenic, can nonetheless be specific biomarkers of cytotoxic T-cell-mediated autoimmune neurologic disorders. ${ }^{1}$ Recently, our group described a class of steroid-responsive inflammatory CNS disorders unified by glial fibrillary acidic protein (GFAP) antibody, a cytoplasmic type III intermediate astrocytic filament. ${ }^{3,4}$ The diagnosis now routinely is made in our clinical laboratory by identification of GFAP-IgG in CSF by tissue-based indirect tissue immunofluorescence assay (IFA) and confirmation by a cell-based assay (CBA) using a GFAPtransfected cell line.

Neuronal intermediate filament (NIF) antibodies have been reported previously among patients with various diseases and healthy controls, generally when tested for by a single assay type such as Western blot or ELISA. ${ }^{5-7}$ Here, we report NIF autoimmunity detected among patients referred for broad screening of neural antibodies by IFA, who had confirmation of NIF specificity by CBAs. Specificities included mature NIF forms ( $\alpha$ internexin $[\alpha \mathrm{IN}]$, neurofilament light chain $[\mathrm{NfL}]$, neurofilament medium chain $[\mathrm{NfM}]$, neurofilament heavy chain $[\mathrm{NfH}]$, and peripherin), but not immature forms (vimentin or nestin) or GFAP. In particular, we focus on a group of patients who had an NIF-IgG profile that included NfL-IgG accompanied by paraneoplastic CNS autoimmunity (usually cerebellar ataxia, encephalopathy, or both) in the context of neuroendocrine neoplasia.

\section{Methods}

\section{Standard protocol approvals, registrations, and patient consents}

The Mayo Clinic Institutional Review Board approved human specimen acquisition and review of patients' histories (IRB 16-009814).

\section{Study population}

The Mayo Clinic Neuroimmunology Laboratory tested by tissue IFA, on a service basis, 616,025 serum and CSF specimens submitted for patients undergoing workup for a suspected paraneoplastic neurologic or autoimmune encephalitic illness. Either of 2 distinctive neuronal filamentous patterns of IgG reactivity was observed by IFA in serum, CSF, or both in 85 patients.

Control specimens tested by both IFA and CBAs ( 257 total: 237 sera, $20 \mathrm{CSF}$ ) were as follows: sera from 33 healthy controls, 63 cancer patients without neurologic symptoms (30 patients with small cell lung carcinoma, 23 patients with hepatocellular carcinoma, and 10 patients with Merkel cell carcinoma), and 20 patients with a diagnosis of a paraneoplastic neurologic disorder (anti-Hu, anti-Yo, 10 patients each), and specimens from 122 patients with diseases in whom neurofilament antibodies were previously reported in the literature including Creutzfeldt-Jakob disease (CJD; 30 sera and $10 \mathrm{CSF}$ ), type I diabetes mellitus (30 sera), CNS systemic lupus erythematous (11 sera and 1 CSF), multiple sclerosis (MS; 20 sera and 9 CSF), and amyotrophic lateral sclerosis (ALS; 30 sera). Some historical noncancer control specimens previously tested by IFA only (354 total) were 288 healthy adult donor sera and $119 \mathrm{CSF}$ from adult patients with either normal pressure hydrocephalus (66) or miscellaneous nonautoimmune neurologic disorders (53; 21 adult, 32 pediatric).

\section{Antigen characterization}

An algorithm demonstrating the strategy for antibody characterization and testing is outlined in figure 1. Patient and control serum and CSF specimens, and commercial monoclonal antibodies, were tested by indirect IFA on cryosections $(4 \mu \mathrm{m})$ of adult mouse tissues: cerebellum, midbrain, cerebral cortex, striatum, hippocampus, kidney, and gut. ${ }^{4} \mathrm{Cutoff}$ values of $\leq 1: 120$ for serum and $\leq 1: 2$ for CSF are long-established and clinically validated in the Mayo Clinic Neuroimmunology Laboratory. The detailed procedures for this and the following are described in data available from Dryad (appendix e-1, doi.org/10.5061/dryad.43vc3c6): (1) antibody characterization (Western blotting, immunoprecipitation, mass spectrometry, antibody purification, and dual staining of tissues and cells with patient specimens and commercial IgGs); (2) NIF antibody profile testing (development of NIF-specific cell lines in-house for CBA); (3) standard clinical neural antibody testing performed; and (4) staining of tumor tissue.

\section{NIF-IgG profile determination by CBA}

Cells from stably transfected NIF-expressing cell lines were plated in 8-well poly-D-lysine-coated chamber slides (Corning; Corning, NY), fixed (4\% paraformaldehyde, 15 minutes), 
Figure 1 Algorithm for antigen characterization and 2-step algorithm for the serologic diagnosis of neuronal intermediate filament (NIF) autoimmunity

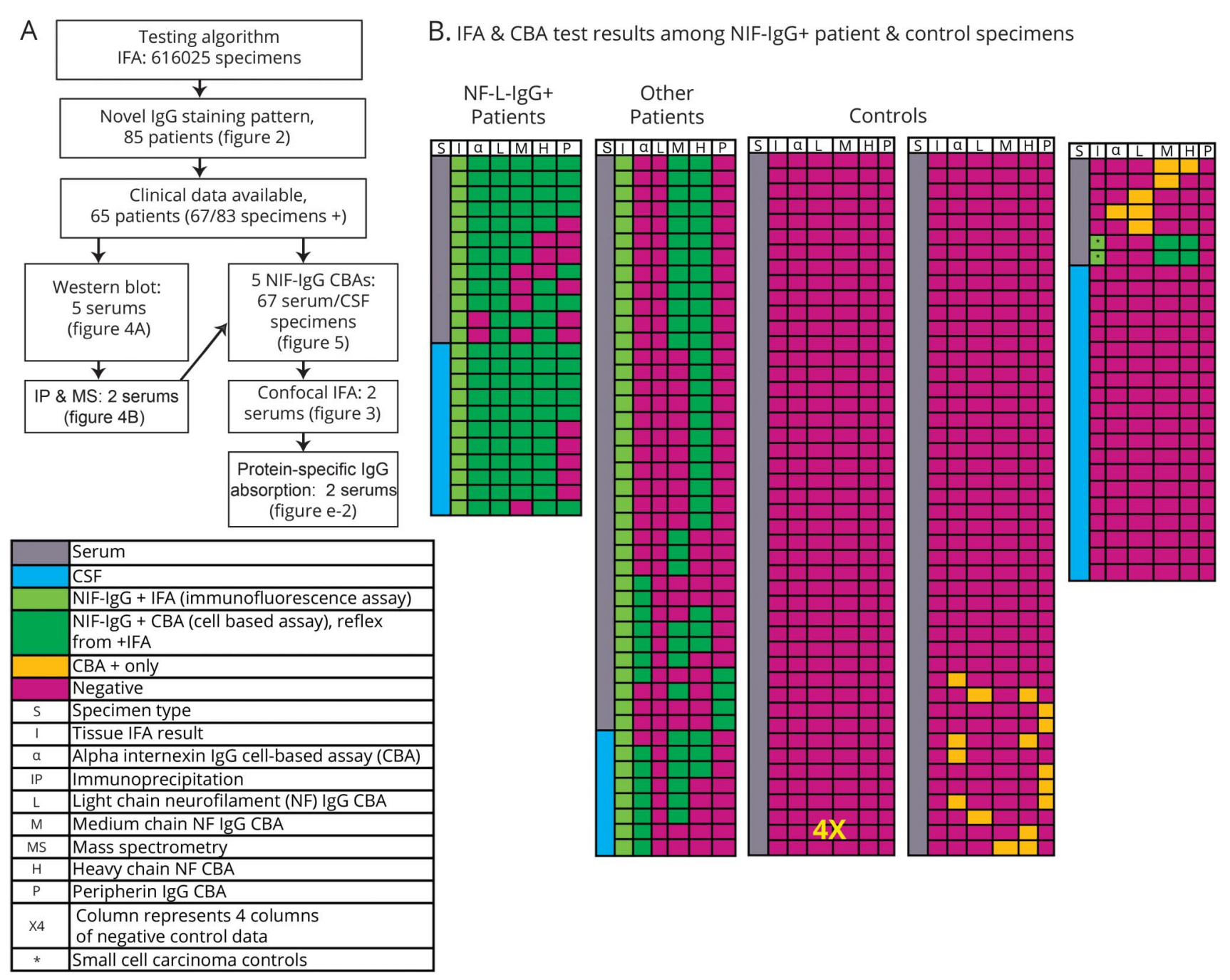

Algorithm for (A) antigen characterization and (B) 2-step algorithm for the serologic diagnosis of NIF autoimmunity. (B) Each row represents 1 specimen from 65 patients (48 sera, 19 CSF) or controls (237 sera, 20 CSF), all tested by both tissue-based immunofluorescence assay (IFA) and all 5 NIF-immunoglobulin G (IgG) cell-based assays (CBAs). Only 2 controls (both with cancer) were IFA- and CBA-positive. Specificity assurance requires positivity by both IFA plus one or more recombinant NIF CBAs. NfL = neurofilament light chain.

and permeabilized (0.2\% Triton-X-100, 10 minutes). Normal goat serum (10\%) was applied for 30 minutes to block nonspecific IgG binding. Patient or control serum (1:600 dilution) and CSF (1:5) were added to the cells for 90 minutes at room temperature. The CBA dilution of 1:600 was the optimized dilution whereby all our patient sera (NIF-IgGpositive by IFA) remained robustly positive (having also been tested with the same results at 1:100, 1:200, and 1:400), with the least amount of nonspecific staining among controls. All of our patient sera and CSF that were IFA-positive remained unambiguously positive at $1: 600$ and $1: 5$, respectively, by CBAs.

Cells were washed in phosphate-buffered saline (PBS) and secondary antibody (TRITC-conjugated goat antihuman IgG, 1:200) was applied for 45 minutes. After washing cells in PBS, slides were mounted in Prolong Gold anti-fade reagent containing 4,6-diamidino-2-phenylindole (Molecular Probes, Eugene, OR).

\section{Statistical methods}

Neurologic disorder type and cancer frequency and histologic type for NIF-IgG patient groups were compared by Fisher exact test (JMP).

\section{Data availability}

Data available from Dryad, doi.org/10.5061/dryad.43vc3c6.

\section{Results}

Between January 1, 1993, and April 30, 2017, the Mayo Clinic Neuroimmunology Laboratory identified 2 distinctive neuronal filamentous-appearing patterns of IgG reactivity by IFA in serum or CSF of 85 patients (with 90 available specimens: 
serum, 65; CSF, 25) among 616,025 serum and CSF specimens tested $(0.014 \%)$. Sixty-five patients with both clinical information and $\geq 1$ specimens available were included.

\section{Autoantibody characterization}

\section{Tissue distribution of immunoreactivity}

Sera (48) and CSF specimens (19) from all 65 patients intensely stained neuronal cytoplasmic filaments throughout the CNS and enteric mouse tissue composite (figure 2, A.a-C.a, E.a-G.a). Non-neural renal and gastrointestinal parenchymal tissues were nonreactive (figure 2, C.a and G.a). In the cerebellum, immunostaining of cerebellar granular layer and peri-Purkinje cell regions was intense in all 65 patients. In 42 patients, immunostaining additionally produced a blush that faded in intensity through the molecular layer, from deep (adjacent to the Purkinje cell layer) to superficial regions (pattern 1, exemplified by patient 21 ; figures $2 \mathrm{~A}$ and $3 \mathrm{~A}$ ).
Pattern 1 had the same appearance as staining produced by commercial IgGs reactive with $\alpha \mathrm{IN}, \mathrm{NfL}$, and NfM (figures $2 \mathrm{D}$ and $3 \mathrm{~A}$ and figure e-1, doi.org/10.5061/dryad.43vc3c6). For the remaining 23 patients, staining of the cerebellar molecular layer was restricted to the peri-Purkinje cell region (pattern 2, exemplified by patient 28; figures $2 \mathrm{E}$ and $3 \mathrm{~B}$ ). Pattern 2 had the same appearance as staining produced by commercial IgG reactive with $\mathrm{NfH}$ (figures $2 \mathrm{H}$ and $3 \mathrm{~B}$ and figure e-1, doi.org/10.5061/dryad.43vc3c6). The patient staining patterns did not resemble those produced by commercial IgGs reactive with nestin, vimentin, or GFAP (figure 3, D-F). Findings among serum and CSF pairs, available for 7 patients, were as follows: positive in both, 2; positive in CSF only, 5 .

Median IFA antibody values were 1:3,840 in serum (range 1: 240-1:245,760; normal value $\leq 1: 120$ ) and 1:8 in CSF (range $2-1,024$; normal value $\leq 1: 2)($ table 1$)$.

Figure 2 Immunofluorescence patterns of patient immunoglobulin G (lgG) binding to mouse tissues.

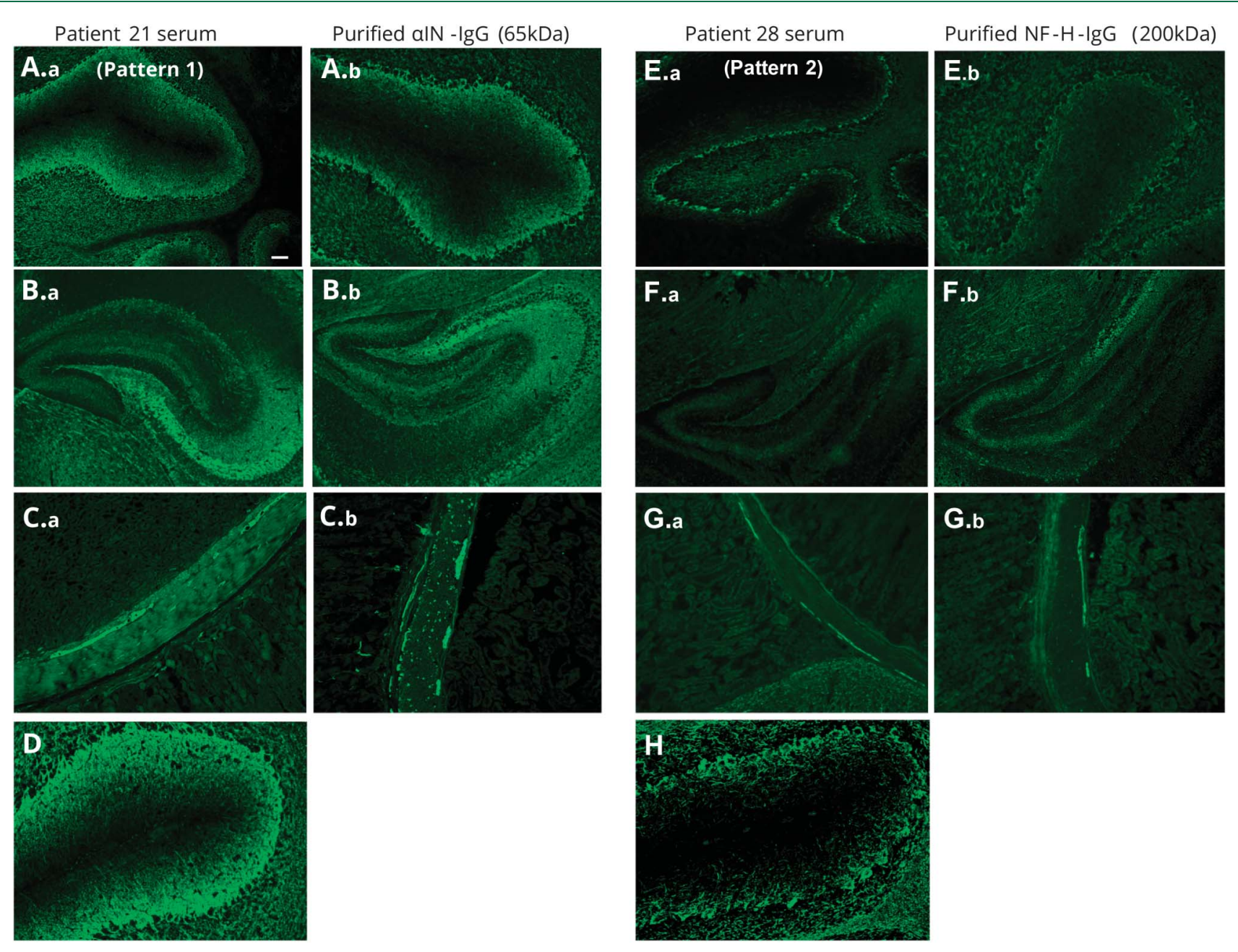

Cerebellum (A, E), hippocampus (B, F), and gastric neuronal ganglia and nerves (C, G) exposed to serum of patient 21 (A.a-C.a) and patient 28 (E.a-G.a) or to IgGs affinity-purified from serum of those patients by acid elution from replicas of Western blotted bands (A.b-C.b [65 kDa] and E2-G2 [200 kDa]). Smooth muscle antibody in patient 21 serum partially obscures the neural staining in C.a but not C.b. For comparison, cerebellar staining by commercial a internexin IgG (D) and neurofilament heavy chain IgG (H) are demonstrated (see also figure e-1). Scale bar = $50 \mu \mathrm{m}$. 
Figure 3 Dual immunostaining of mouse cerebellum with patient immunoglobulin $\mathrm{G}$ (lgG) and IgG specific for neuronal or astrocytic intermediate filaments (IF)
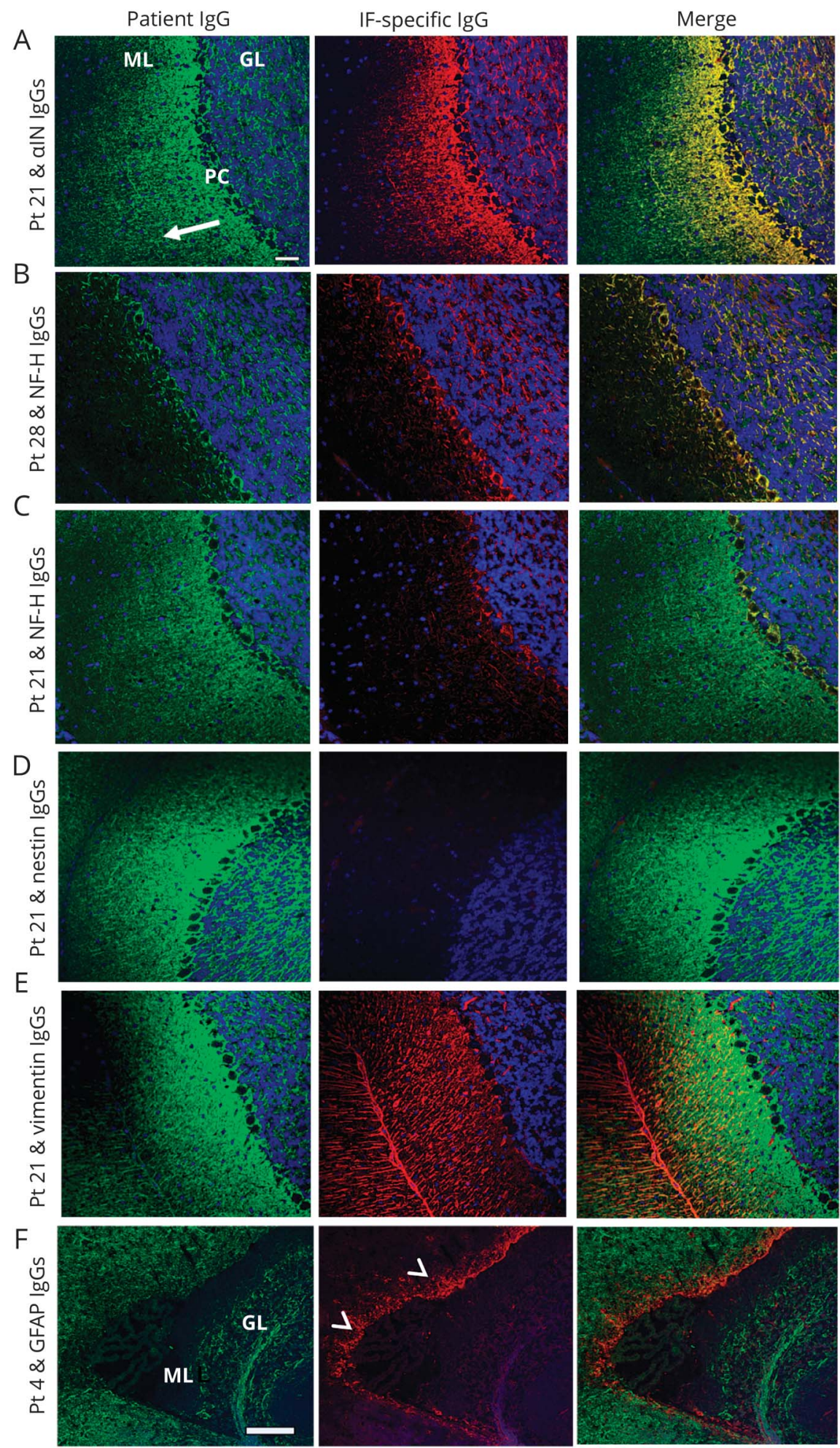

Patient IgG (Pt, green) binding to mouse cerebellar cortex colocalizes with commercial IgGs (red) specific for ainternexin (alN) IgG or neurofilament heavy $(\mathrm{NfH})$ IgG (yellow in merge), but not with nestin, vimentin, or glial fibrillary acidic protein (GFAP). (A) Patient 21 serum (pattern 1) yields a filamentous pattern in the molecular layer (ML), Purkinje cell layer (PC), and granular layer (GL). Staining, most intense in $\mathrm{ML}$ and gradually fading from deep to superficial regions (arrow), colocalizes with alN IgG. (B) Patient 28 serum (pattern 2) yields a staining pattern mostly restricted to the GL and PC layer, and colocalizes with NfH IgG. (C) Patient 21 serum partially colocalizes with $\mathrm{NfH} / \mathrm{gG}$, but not with early developmental neuronal intermediate filaments (nestin [D], vimentin [E]). Patient 4 serum (pattern 1) does not colocalize with GFAP (F) which, characteristically, is most prominent in the subventricular zone (arrowheads; the choroid plexus is nonstained). Scale bar $=20 \mu \mathrm{m}$ except for $\mathrm{F}=100 \mu \mathrm{m}$.

\section{Immunochemical characterization using rat spinal cord}

Western blot probing of rat spinal cord proteins with 5 sera (from patients 1, 2, 12, 13, and 17 [lanes 6-10, respectively], figure $4 \mathrm{~A}$ ) revealed one or more immunoreactive bands of interest per patient. Five control human IgGs were nonreactive. For patients 12 and 17, the bands with approximate $\mathrm{kDa}$ molecular weights of 200, 150, 70, and 65 (the same as those produced by CNS-predominant NIF-specific commercial IgGs [ $\alpha \mathrm{IN}, \mathrm{NfL}, \mathrm{NfM}$, and $\mathrm{NfH}$; figure $4 \mathrm{~A}]$ ) were 
Table 1 Neurofilament light chain (NfL)-immunoglobulin G (IgG)-positive patients

\begin{tabular}{|c|c|c|c|c|c|c|c|}
\hline $\begin{array}{l}\text { Study no./ } \\
\text { sex/age, y/ } \\
\text { IFA pattern }\end{array}$ & $\begin{array}{l}\text { Serum } \\
\text { NIF-IgG } \\
\text { profile }\end{array}$ & $\begin{array}{l}\text { CSF NIF- } \\
\text { IgG profile }\end{array}$ & Presenting symptoms & $\begin{array}{l}\text { Neurologic } \\
\text { disorder }\end{array}$ & Cancer & MRI findings & Other test findings \\
\hline 1/M/74/1 & $\begin{array}{l}\text { aLMH, } \\
30,720\end{array}$ & NA & $\begin{array}{l}\text { Imbalance, incoordination, } \\
\text { diplopia }\end{array}$ & Cerebellar ataxia & None & NA & NA \\
\hline $2 / \mathrm{M} / 80^{\mathrm{a}} / 1$ & $\begin{array}{l}\text { aLMHP, } \\
30,720\end{array}$ & NA & Imbalance, incoordination & $\begin{array}{l}\text { Cerebellar ataxia, } \\
\text { peripheral } \\
\text { neuropathy }\end{array}$ & Non-Hodgkin lymphoma & NA & Length-dependent axonal neuropathy \\
\hline 3/F/64/1 & Neg & aLMH, 4 & $\begin{array}{l}\text { Imbalance, incoordination, limb } \\
\text { paresthesias }\end{array}$ & $\begin{array}{l}\text { Cerebellar ataxia, } \\
\text { peripheral } \\
\text { neuropathy }\end{array}$ & Leiomyosarcoma & NA & $\begin{array}{l}\text { Length-dependent axonal neuropathy; GAD65 } \\
(397 \mathrm{nM})\end{array}$ \\
\hline 4/F/74/1 & $\begin{array}{l}\text { aLHP, } \\
3,840\end{array}$ & $\begin{array}{l}\text { aLMHP, } \\
512\end{array}$ & $\begin{array}{l}\text { Confusion, memory loss, } \\
\text { imbalance, incoordination }^{\text {b }}\end{array}$ & $\begin{array}{l}\text { Cerebellar ataxia, } \\
\text { encephalopathy }\end{array}$ & Merkel cell carcinoma & NA & $\begin{array}{l}\text { WBCs 11; pro 150; OCB, 5; CRMP5-IgG 1:15,360; } \\
\text { VGKC } 0.22 \mathrm{nM}^{\mathrm{c}}\end{array}$ \\
\hline $5 / F / 55 / 1$ & NA & aLMHP, 4 & Diffuse pain & $\begin{array}{l}\text { Carcinomatous } \\
\text { meningitis }\end{array}$ & SCLC & Head/spine: meningeal enhancement & CSF: SCLC cells \\
\hline 6/F/64/1 & $\begin{array}{l}\text { aLM, } \\
480\end{array}$ & NA & $\begin{array}{l}\text { Developed confusion, memory } \\
\text { loss }^{\text {b }}\end{array}$ & Encephalopathy & Non-SCLC & NA & NA \\
\hline $7 / M / 52^{a} / 1$ & NA & aLMH, 64 & $\begin{array}{l}\text { Cognitive symptoms; anxiety } \\
\text { and depression, suicidal }\end{array}$ & $\begin{array}{l}\text { Encephalopathy } \\
\text { (limbic } \\
\text { encephalitis) }\end{array}$ & None & Bilateral limbic encephalitis & $\begin{array}{l}\text { Normal EEG; CSF: WBCs, } 6,87 \% \text { lymphs; pro 61; } \\
\text { IgG index 0.95; IgG synth 16.62; OCB negative; } \\
\text { VGCC-P/Q (0.18 nM), VGCC-N (0.05 nM) }\end{array}$ \\
\hline $8 / F / 74^{a} / 1$ & NA & $\begin{array}{l}\text { aLMH, } \\
1024\end{array}$ & $\begin{array}{l}\text { Nausea, vertigo, diplopia, } \\
\text { imbalance, incoordination, } \\
\text { dysarthria, and dysphagia }\end{array}$ & Cerebellar ataxia & $\begin{array}{l}\text { Metastatic Merkel cell } \\
\text { carcinoma to inguinal } \\
\text { lymph node }\end{array}$ & Mild cerebellar volume loss & $\begin{array}{l}\text { Pro } 44,32 \text { cells, } 72 \% \text { lymphs; other indices } \\
\text { normal }\end{array}$ \\
\hline 9/F/60/1 & NA & aLMHP, 16 & $\begin{array}{l}\text { Paresthesias in face and arms, } \\
\text { lower extremity weakness and } \\
\text { spasticity }\end{array}$ & Myelopathy & SCLC & NA & Elevated CSF protein \\
\hline 10/M/64/1 & NA & $\begin{array}{l}\text { aLMH, } \\
1024\end{array}$ & $\begin{array}{l}\text { Progressive gait and balance } \\
\text { difficulties }\end{array}$ & Cerebellar ataxia & SCLC & NA & NA \\
\hline $11 / F / 47^{a} / 1$ & $\begin{array}{l}\text { aLP, } \\
1,920\end{array}$ & NA & $\begin{array}{l}\text { Rapid cognitive decline, } \\
\text { catatonia, dyskinesias }\end{array}$ & $\begin{array}{l}\text { Encephalopathy, } \\
\text { chorea }\end{array}$ & SCLC & Head, normal & $\begin{array}{l}\text { EEG: dysrhythmia grade } 3 \text { bifrontal; CSF: } 4 \text { OCB, } \\
\text { normal otherwise; NMDAR IgG positive, CSF } \\
\text { (titer 1:4); VGKC } 0.10 \mathrm{nM}^{\mathrm{c}}\end{array}$ \\
\hline $12 / M / 66^{a} / 1$ & $\begin{array}{l}\text { aLMHP, } \\
61,440\end{array}$ & NA & $\begin{array}{l}\text { Gait and balance difficulties, } \\
\text { dysarthria, incoordination, } \\
\text { vision loss }\end{array}$ & $\begin{array}{l}\text { Cerebellar ataxia, } \\
\text { retinopathy }\end{array}$ & $\begin{array}{l}\text { Neuroendocrine } \\
\text { carcinoma metastatic; } \\
\text { prostate adenocarcinoma } \\
\text { (history) }\end{array}$ & Head, normal & $\begin{array}{l}\text { EMG: sensorimotor axonal neuropathy; CSF: } \\
\text { Pro } 69 \text { mg/dL, otherwise normal; VGCC-N } 0.08 \\
\text { nM, VGCC-P/Q } 0.03 \text { nM }\end{array}$ \\
\hline 13/M/63/1 & $\begin{array}{l}\text { aLMHP, } \\
122,880\end{array}$ & NA & $\begin{array}{l}\text { Subacute cognitive decline, } \\
\text { diplopia }\end{array}$ & $\begin{array}{l}\text { Encephalopathy, } \\
\text { cranial } \\
\text { neuropathies }\end{array}$ & Hepatocellular carcinoma & $\begin{array}{l}\text { Enhancement of bilateral III and Vth } \\
\text { CNs }\end{array}$ & NA \\
\hline
\end{tabular}




\begin{tabular}{|c|c|c|c|c|c|c|c|}
\hline $\begin{array}{l}\text { Study no./ } \\
\text { sex/age, y/ } \\
\text { IFA pattern }\end{array}$ & $\begin{array}{l}\text { Serum } \\
\text { NIF-IgG } \\
\text { profile }\end{array}$ & $\begin{array}{l}\text { CSF NIF- } \\
\text { IgG profile }\end{array}$ & Presenting symptoms & $\begin{array}{l}\text { Neurologic } \\
\text { disorder }\end{array}$ & Cancer & MRI findings & Other test findings \\
\hline 14/F/62/1 & $\begin{array}{l}\text { aLMHP, } \\
7,680\end{array}$ & NA & $\begin{array}{l}\text { Disoriented, visual and tactile } \\
\text { hallucinations, severe gait and } \\
\text { coordination difficulties }\end{array}$ & $\begin{array}{l}\text { Cerebellar ataxia, } \\
\text { encephalopathy }\end{array}$ & $\begin{array}{l}\text { Tibial Merkel cell } \\
\text { carcinoma }\end{array}$ & Head, normal & CSF pro, 300 mg/dL, WBCs 97, 95\% lymphs \\
\hline $15 / F / 74^{\mathrm{a} / 1}$ & NA & $\begin{array}{l}\text { aLMHP, } \\
1024\end{array}$ & $\begin{array}{l}\text { Leg pain, vertigo, left facial } \\
\text { weakness, spasticity of legs }\end{array}$ & $\begin{array}{l}\text { Encephalopathy, } \\
\text { cranial } \\
\text { neuropathy, } \\
\text { myelopathy }\end{array}$ & $\begin{array}{l}\text { Small cell carcinoma of } \\
\text { cervical lymph node } \\
\text { (unknown primary) }\end{array}$ & $\begin{array}{l}\text { Enhancing left facial nerve; T2 signal in } \\
\text { the brainstem, corticospinal tracts from } \\
\text { precentral gyrus to the medulla }\end{array}$ & $\begin{array}{l}\text { EMG: bilateral facial neuropathies; CSF: Pro } 77 \\
\text { mg/dL, WBCs, } 11,90 \% \text { lymphs; IgG synth } 37.68 \\
\text { OCB, 9; IgG index } 2.5\end{array}$ \\
\hline 16/M/66/1 & $\begin{array}{l}\mathrm{LH}, \\
7,680\end{array}$ & NA & $\begin{array}{l}\text { Intermittent vertigo, vomiting, } \\
\text { erectile dysfunction, early } \\
\text { satiety, orthostatic } \\
\text { lightheadedness }\end{array}$ & $\begin{array}{l}\text { Episodic } \\
\text { cerebellar ataxia, } \\
\text { dysautonomia }\end{array}$ & None & NA & NA \\
\hline $37 / M / 62 / 1$ & $\begin{array}{l}\text { aLM, } \\
122,880\end{array}$ & NA & $\begin{array}{l}\text { Confusion, episodes of } \\
\text { depersonalization }\end{array}$ & Encephalopathy & Hepatocellular & NA & NA \\
\hline $54 / M / 56 / 1$ & $\begin{array}{l}\mathrm{aLH}, \\
3,840\end{array}$ & NA & Numb feet and hands & $\begin{array}{l}\text { Peripheral } \\
\text { neuropathy }\end{array}$ & T-cell lymphoma & NA & NA \\
\hline $55 / F / 61^{a} / 1$ & Neg & aLHP, NA & $\begin{array}{l}\text { Pain and weakness in arms, } \\
\text { bilateral ptosis, tongue } \\
\text { weakness }\end{array}$ & $\begin{array}{l}\text { Encephalopathy, } \\
\text { cranial } \\
\text { neuropathies }\end{array}$ & Nil & Head, normal & $\begin{array}{l}\text { EMG neurogenic changes, bulbar segment } \\
\text { (nonprogressive) }\end{array}$ \\
\hline $58 / \mathrm{M} / 68 / 1$ & Neg & aLMH, 4 & $\begin{array}{l}\text { Profound gait, balance, and } \\
\text { coordination problems, } \\
\text { cognitive decline }\end{array}$ & $\begin{array}{l}\text { Cerebellar ataxia, } \\
\text { encephalopathy }\end{array}$ & Nil & NA & CSF: Pro 88 mg/dL; WBCs, 26, 90\% lymphs \\
\hline $59 / \mathrm{M} / 87^{\mathrm{a}} / 1$ & $\begin{array}{l}\mathrm{LMH}, \\
480\end{array}$ & aLMHP, 4 & $\begin{array}{l}\text { Coarse tremor of head and } \\
\text { extremities, gait and balance } \\
\text { difficulties, delirium }\end{array}$ & $\begin{array}{l}\text { Cerebellar ataxia, } \\
\text { encephalopathy }\end{array}$ & $\begin{array}{l}\text { Pancreatic cystic } \\
\text { neuroendocrine }\end{array}$ & $\begin{array}{l}\text { T2 signal abnormality and atrophy in } \\
\text { cerebellum }\end{array}$ & CSF: Pro $46 \mathrm{mg} / \mathrm{dL}$ \\
\hline $\begin{array}{l}\text { Abbreviation } \\
\text { immunoglob } \\
\text { light chain ar } \\
\text { rescence ass } \\
\text { Gs; lymphs = } \\
\text { Pro = protein } \\
\text { a Mayo Clinic } \\
\text { b After check } \\
\text { 'LGI1/CASPR }\end{array}$ & $\begin{array}{l}\text { aLH }=a \text { ir } \\
\text { in Gs; aLM } \\
\text { I peripherir } \\
\text {; IgG synth } \\
\text { mphocytes } \\
\text { SCLC = sm } \\
\text { atient. } \\
\text { int inhibitc } \\
\text { IgGs negat }\end{array}$ & $\begin{array}{l}\text { ernexin, light } \\
=\text { a internexin } \\
\text { immunoglobu } \\
\text { : immunoglob } \\
\text { NA = not avail } \\
\text { I cell lung carc } \\
\text { (against PD-1 } \\
\text { e. }\end{array}$ & $\begin{array}{l}\text { hain and heavy chain immunogl } \\
\text { light chain, medium chain, and he } \\
\text { in Gs; CASPR2 = contactin-associ } \\
\text { lin G synthesis rate; LGI1 = leucine } \\
\text { ble; Neg = negative; NIF = neurona } \\
\text { noma; VGCC-N = N-type voltage \& } \\
\text { therapy for cancer. }\end{array}$ & $\begin{array}{l}\text { lin Gs; aLHP = a int } \\
\text { chain immunoglobs } \\
\text { protein 2; CRMP-5 } \\
\text { nglioma inactivated } \\
\text { ermediate filaments } \\
\text { d calcium channel; }\end{array}$ & $\begin{array}{l}\text { rnexin, light chain, heavy } \\
\text { in Gs; aLMHP = a internex } \\
\text { collapsin-response medi } \\
\text {; LH = light chain and hea } \\
\text { nM = nanomolar (nmol/L) } \\
\text { GCC-P/Q = P/Q-type volta }\end{array}$ & $\begin{array}{l}\text { in, and peripherin immunoglobulin Gs; a } \\
\text { ht chain, medium chain, heavy chain, and } \\
\text { protein-5; GAD } 65 \text { = glutamic acid decarbc } \\
\text { lain immunoglobulin Gs; LMH = light chain } \\
\text { DAR = NMDA receptor; OCB = oligoclonal b } \\
\text { ted calcium channel; WBCs = white blood }\end{array}$ & $\begin{array}{l}\text { M = a internexin, light chain and medium chair } \\
\text { eripherin immunoglobulin Gs; } a \mathrm{LP}=a \text { internexin } \\
\text { xylase, } 65 \text { kilodalton isoform; IFA = immunofluo } \\
\text { medium chain, and heavy chain immunoglobuli } \\
\text { Inds; P = peripherin; PD-1 = programmed death- } 1 \\
\text { cells. }\end{array}$ \\
\hline
\end{tabular}



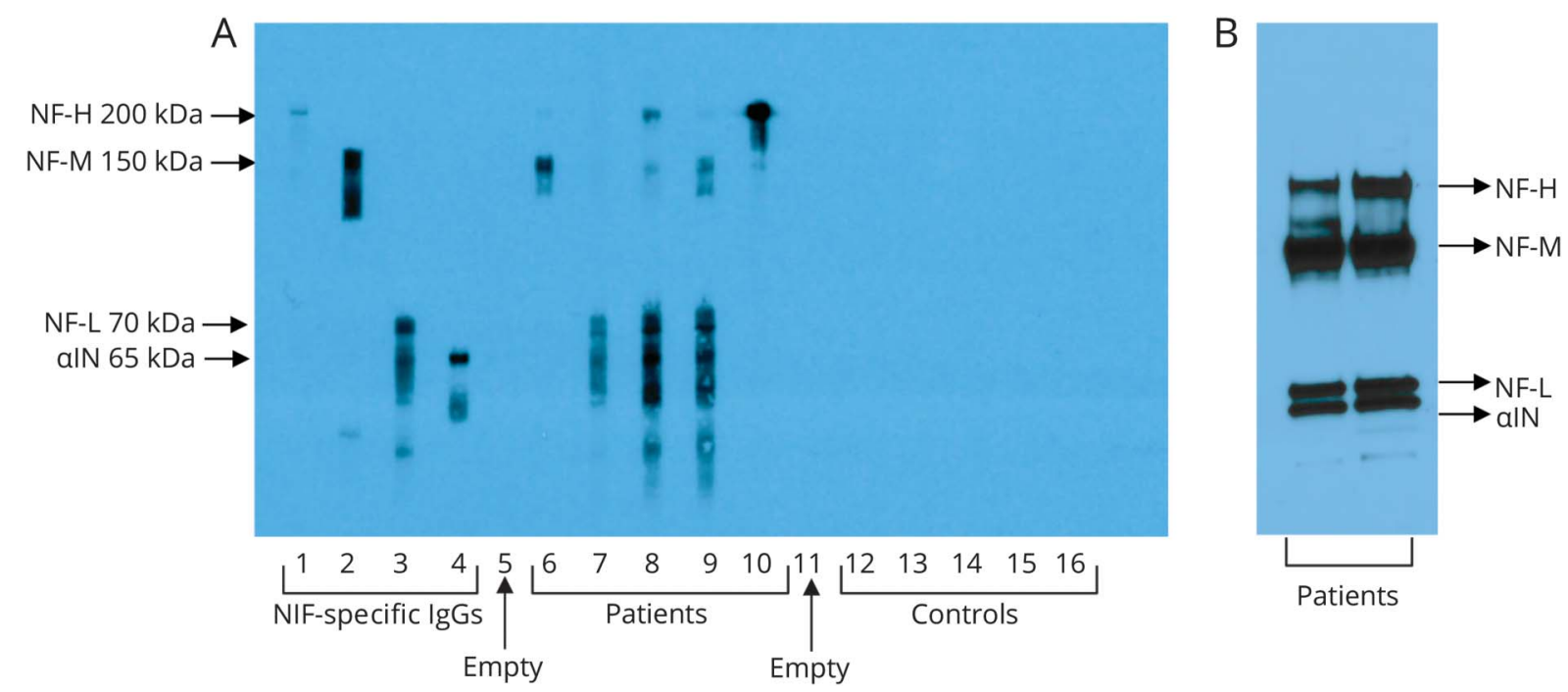

(A) Rat spinal cord proteins, reduced, denatured, and separated electrophoretically, were probed with commercial neuronal intermediate filament (NIF) immunoglobulin $\mathrm{G}(\operatorname{IgG})$ (lanes 1-4), patient IgG (patients 1, 2, 12, 13, and 17 are in lanes 6-10, respectively), or healthy control Ig (lanes 12-16). Lanes 5 and 11 are empty. Patient IgGs bind to 2 or more prominent bands (molecular weight $65 \mathrm{kDa}, 70 \mathrm{kDa}, 150 \mathrm{kDa}$, or $200 \mathrm{kDa}$ ), consistent with a internexin (alN), neurofilament light chain (NfL), neurofilament medium chain (NfM), and neurofilament heavy chain (NfH). (B) Proteins from rat spinal cord lysate bound by patient IgGs (12 [left] and 17 [right]) and immunoprecipitated by adsorption to protein G-complexed magnetic beads were separated electrophoretically and subjected to Western blot. Probing with 4 commercial IgGs specific for $\mathrm{NfH}, \mathrm{NfM}, \mathrm{NfL}$, and alN revealed bands with anticipated molecular weights for those NIF proteins. The corresponding proteins were analyzed by mass spectrometry.

selected for an immunoprecipitation study. Analysis by in-gel digestion and mass spectrometry of proteins captured by IgGs from those 2 patients, after immobilization on magnetic beads (figure 4B), assigned the greatest number of polypeptides to $\mathrm{NfH}$ (for the $200 \mathrm{kDa}$ band), $\mathrm{NfM}$ (for the 150 $\mathrm{kDa}$ band), NfL (for the $70 \mathrm{kDa}$ band), and $\alpha \mathrm{IN}$ (for the 65 $\mathrm{kDa}$ band). Antigenicity inherent in the 65 and $200 \mathrm{kDa}$ proteins (representative of pattern 1 and pattern 2, respectively) was further demonstrated by reapplying to tissue sections patient IgGs acid-eluted from replicate bands not subjected to Western blotting (figure 2, A.b-C.b and E.b-G.b).

\section{Absorption experiments}

Tissue IFA staining patterns produced by sera from patient 22 (pattern 1, aIN-IgG positive only) and patient 28 (pattern 2, NfH-IgG positive only) were specifically abolished by preincubating sera with recombinant human aIN and $\mathrm{NfH}$, respectively (figure e-2, doi.org/10.5061/dryad. $43 v c 3 c 6)$. However, recombinant human $\alpha \mathrm{IN}$ had no effect on $\mathrm{NfH}-\mathrm{IgG}$ reactivity of serum from patient 28 , and $\mathrm{NfH}$ had no effect on $\alpha \mathrm{IN}$-IgG reactivity of serum from patient 22 (data not shown). Tissue IFA staining produced by sera from 3 patients with diverse NIF-IgG profiles (patients 1, 12 , and 17) were unaffected by preincubating sera with different concentrations of the polypeptide region of coil $2 \mathrm{~B}$ rod domain, an identical region common to all of $\alpha \mathrm{IN}, \mathrm{NfL}$, $\mathrm{NfM}$, and $\mathrm{NfH}$ (data not shown), consistent with the patient's NIF-IgG profile being polyclonal rather than monoclonal.

\section{Cell-based assay}

HEK293 cells were transfected with expression plasmids encoding individual human intermediate NIFs tagged with GFP. Specificity of the NIF cell lines was confirmed by Western blotting a lysate of each using commercial NIFspecific IgGs (data not shown). Commercial NIF-specific IgGs, control and patient sera, and CSF specimens were evaluated by indirect immunofluorescence after fixation and permeabilization of cells (figure 5 and figure e-3, doi.org/10. 5061/dryad.43vc3c6). IgG to another NIF (peripherin-IgG) was also tested for by the same method. This was done because our patients produced staining of myenteric and renal autonomic nerves indistinguishable from peripherin-IgG (figure e-4, doi.org/10.5061/dryad.43vc3c6) and most patients had more than 1 of the other NIF-IgGs detected. ${ }^{8}$ Each NIF-specific IgG only produced visible reactivity with its cognate antigen designated by the manufacturer (doi.org/10. 5061/dryad.43vc3c6).

\section{Only 2 controls were NIF-IgG-positive by both IFA and CBA; both had small cell carcinoma}

Among 257 control specimens tested by both IFA and CBAs, NIF-IgGs were detected by CBAs in 19 (7\%: median number of positives, 1 [range 1-2]; table e-1, doi.org/10.5061/dryad. $43 \mathrm{vc} 3 \mathrm{c} 6$ and figure 1); always in serum. These positive findings were among 8 of 63 with cancer and no neurologic symptoms (13\%; $4 / 23$ with hepatocellular carcinoma [17\%] and $4 / 30$ with small cell carcinoma of lung [13\%]), 4 of 30 with type 1 diabetes mellitus (13\%), 2 of 20 with paraneoplastic neurologic disorders (10\%), 2 of 33 healthy controls 
Figure 5 Patient immunoglobulin G (IgG) binding to HEK-293 cells transfected with cDNAs encoding green-fluorescent protein (GFP)-tagged human neuronal intermediate filaments (NIFs)
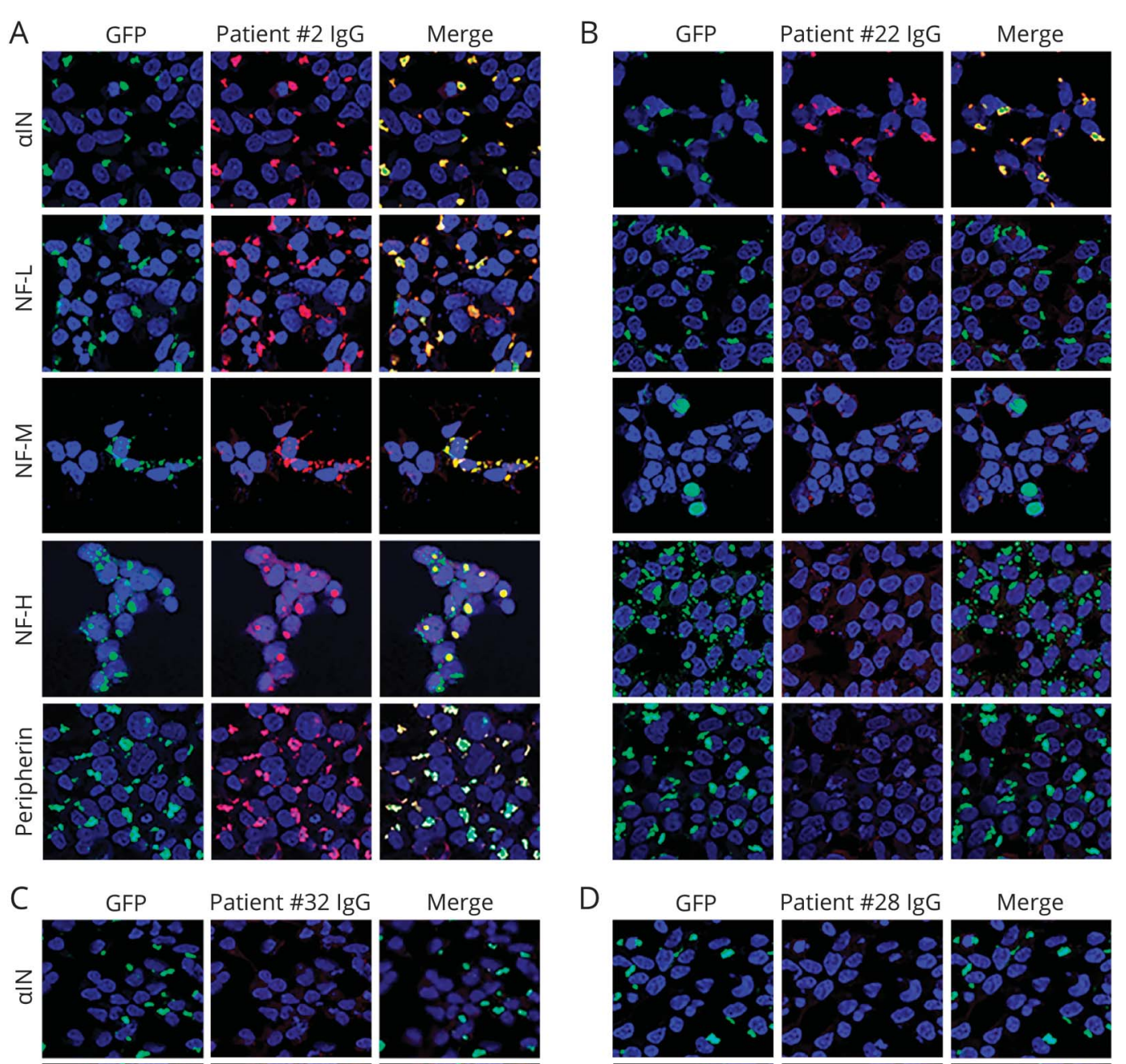

D
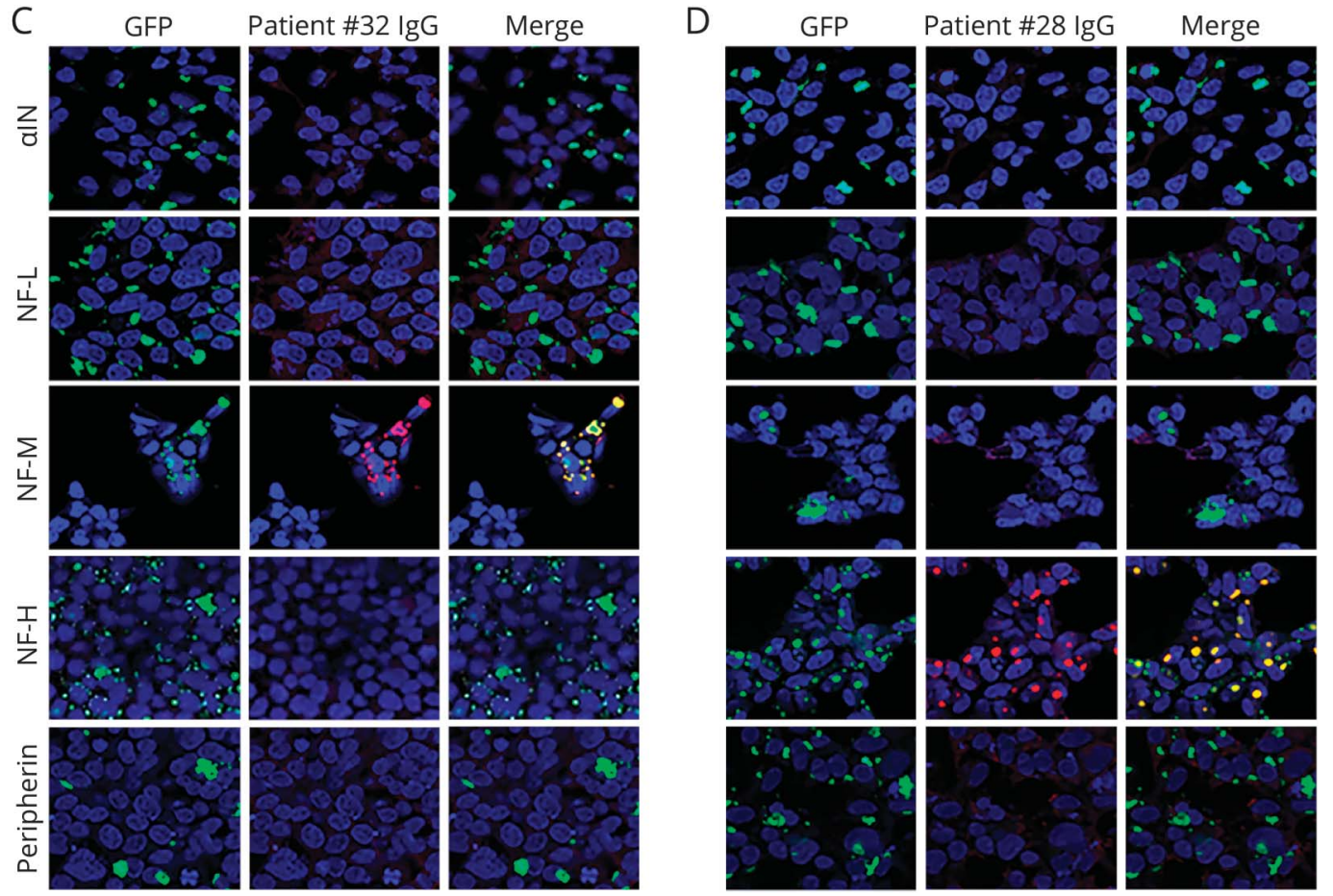

Patient IgGs (red) had diverse NIF reactivities. Illustrative examples include (A) patient 2 serum bound to a internexin (aIN), neurofilament light chain (NfL), neurofilament medium chain ( $\mathrm{NfM}$ ), neurofilament heavy chain ( $\mathrm{NfH}$ ), and peripherin; (B) patient 22 serum bound solely to alN; (C) patient 32 serum bound to $\mathrm{NfM}$ only; and (D) patient 28 serum bound to $\mathrm{NfH}$ only. Scale bar $=20 \mu \mathrm{m}$. 
(6\%), 1 of 30 with CJD (3\%), 1 of 29 with MS (3\%), and 1 of 30 with ALS (3\%). Only 2 control sera were positive by both IFA and CBA; both had small cell carcinoma (both had pattern 1 on IFA). All CSF controls were negative by IFA and CBAs. All 354 historical control specimens screened by tissue IFA alone were negative.

\section{Patients were NIF-IgG-positive by both IFA and CBA}

Of 65 patients, 33 were female (51\%). Median age at neurologic symptom onset was 62 years (range 18-88 years). Forty-seven sera and 21 CSF were IFA-positive and were confirmed by CBA to have 1 or more NIF-IgG specificity (table e-1, doi.org/10.5061/dryad.43vc3c6; figure 1). NIFIgG specificities detected in serum or CSF by CBAs for the 65 patients were $\geq 1$ of the following: $\alpha \mathrm{IN}, 34$; NfL, 21 ; NfM, 42 ; $\mathrm{NfH}, 47$; peripherin, 14 . Eleven patients had repeat specimens (6 sera, 5 CSF) submitted within 2 years, all of which remained positive with the same profile. Patients fell into 2 distinct clinical groups, based on the presence or absence of NfL-IgG in the profile.

\section{NfL-IgG-positive patients have CNS paraneoplastic autoimmunity}

There were 21 patients with a profile of NIF-IgGs that included NfL-IgG. All had pattern 1 by IFA, and 3 were positive in CSF only. The median number of NIF-IgGs positive was 4 (range 2-5). Eight were evaluated neurologically at Mayo Clinic.

Cancers contemporaneous with the onset of neurologic symptoms were detected in 16 of 21 patients (positive predictive value of $77 \%$, table 1), 2 whose neurologic symptoms started after antiT-cell regulatory checkpoint inhibitor therapy for cancer. Thirteen of the remaining 14 cancers were detected within 3 months after serum or CSF draw for antibody testing. Carcinomas of neuroendocrine lineage (10; 49\% of all 21 patients) were most common: small cell carcinoma (5), Merkel cell carcinoma (3, metastatic and of unknown skin primary in 2), pancreatic neuroendocrine (1), and metastatic neuroendocrine of unknown primary (1). Other neoplasms included hepatocellular carcinoma (2), non-Hodgkin lymphoma (2), uterine leiomyosarcoma (1), and non-small cell lung carcinoma (1). Duration of follow-up was short (median, 2 months; range 0-36).

Nineteen of 21 patients had subacute onset neurologic disorders affecting the CNS (table 1). The other 2 had either peripheral neuropathy (in the context of chemotherapy for T-cell lymphoma, bone marrow transplant, and graft-versushost disease) or carcinomatous meningitis (in the context of small cell carcinoma). Neurologic diagnoses among the 19 patients were cerebellar ataxia $(11 ; 58 \%)$, encephalopathy (11;58\%), and myelopathy $(2 ; 11 \%)$. Four patients had encephalopathy and cerebellar ataxia coexisting (22\%), 3 patients had encephalopathy and cranial neuropathies coexisting (16\%), and 1 had encephalopathy and myelopathy coexisting (5\%). Other coexisting disorders were peripheral neuropathy (2) and dysautonomia (1). Those with ataxia had rapidly progressive gait and coordination difficulties and appendicular cerebellar signs. Those with encephalopathy had subacute onset delirium and memory difficulties in all, and psychiatric symptoms in 4 . Only 1 patient had classical limbic encephalitis. One 47-year-old woman with encephalitis had NMDA-receptor IgG coexisting, accompanied by small cell lung carcinoma, rather than ovarian teratoma. Overall, this NIF-IgG profile was $100 \%$ specific for having $\geq 1$ of encephalopathy, cerebellar ataxia, or cancer.

At presentation, 4 of 9 patients with data available had normal head MRI scans. Abnormal findings (figure e-5, doi.org/10. 5061/dryad.43vc3c6) were cerebellar atrophy in 2 ataxic patients ( 1 also had T2 signal abnormalities), bilateral hippocampal $\mathrm{T} 2$ signal abnormalities in a patient with limbic encephalitis, and cranial nerve enhancement in 2 patients with cranial neuropathies ( 1 with encephalomyelopathy also had diffuse brain and cord T2 signal abnormalities). Seven of 10 patients with data available had inflammatory CSF (elevated lymphocyte-predominant white cell counts or CSF-restricted oligoclonal bands) (table 1). Immunotherapy information was available for 7 patients (table e-2, doi.org/10.5061/dryad. $43 \mathrm{vc} 3 \mathrm{c} 6$ ), 5 of whom improved. Four patients had progressive neurologic symptoms and died, one of whom had received immunotherapy.

\section{NfL-IgG-negative patients had findings of uncertain clinical significance}

The remaining 44 patients were NfL-IgG-negative (21 with pattern 1 by IFA, and 23 with pattern 2 ) (table e-3, doi.org/10. 5061/dryad.43vc3c6). Those patients, as compared to the NfL-IgG-positive group, had diverse neurologic disorders that were less commonly CNS syndromes (27/44 vs $19 / 21, p=$ $0.006)$. Neurologic phenotypes included $\geq 1$ of cognitive disorders, 18; peripheral neuropathy, 14; ataxia, 8; myelopathy, 5; anterior horn cell disorders, 2 ; optic neuropathies, 2 ; chorea, 2; and one each of demyelinating disease, myopathy, and retinopathy. These patients also less frequently had cancer (15/44 vs $16 / 21, p=0.003)$, and were less likely to have cancers of neuroendocrine lineage $(1 / 44$ vs $10 / 21, p<0.0001)$. The median NIF antibody-positive number was lower than in the NfL-IgG cases (2; range, 1-3), and NF-H-IgG predominated.

\section{Merkel cell tumor pathology}

Patient 8 , with severe pancerebellar ataxia, was seropositive for all NIF-IgGs with the exception of peripherin IgG. Her enlarged groin lymph node had immunohistochemical findings characteristic of Merkel cell carcinoma with diffuse reactivity for both cytokeratins (AE1/AE3 and CK-20) and neuroendocrine cells (synaptophysin). In addition, immunostaining was positive for $\alpha \mathrm{IN}, \mathrm{NfL}, \mathrm{NfM}$, and $\mathrm{NfH}$, but not peripherin (figure 6).

\section{Discussion}

We have described a class of paraneoplastic neurologic disorder, diagnosable by screening serum or CSF for a distinctive pattern of NIF-IgG by IFA (pattern 1), and then confirming 


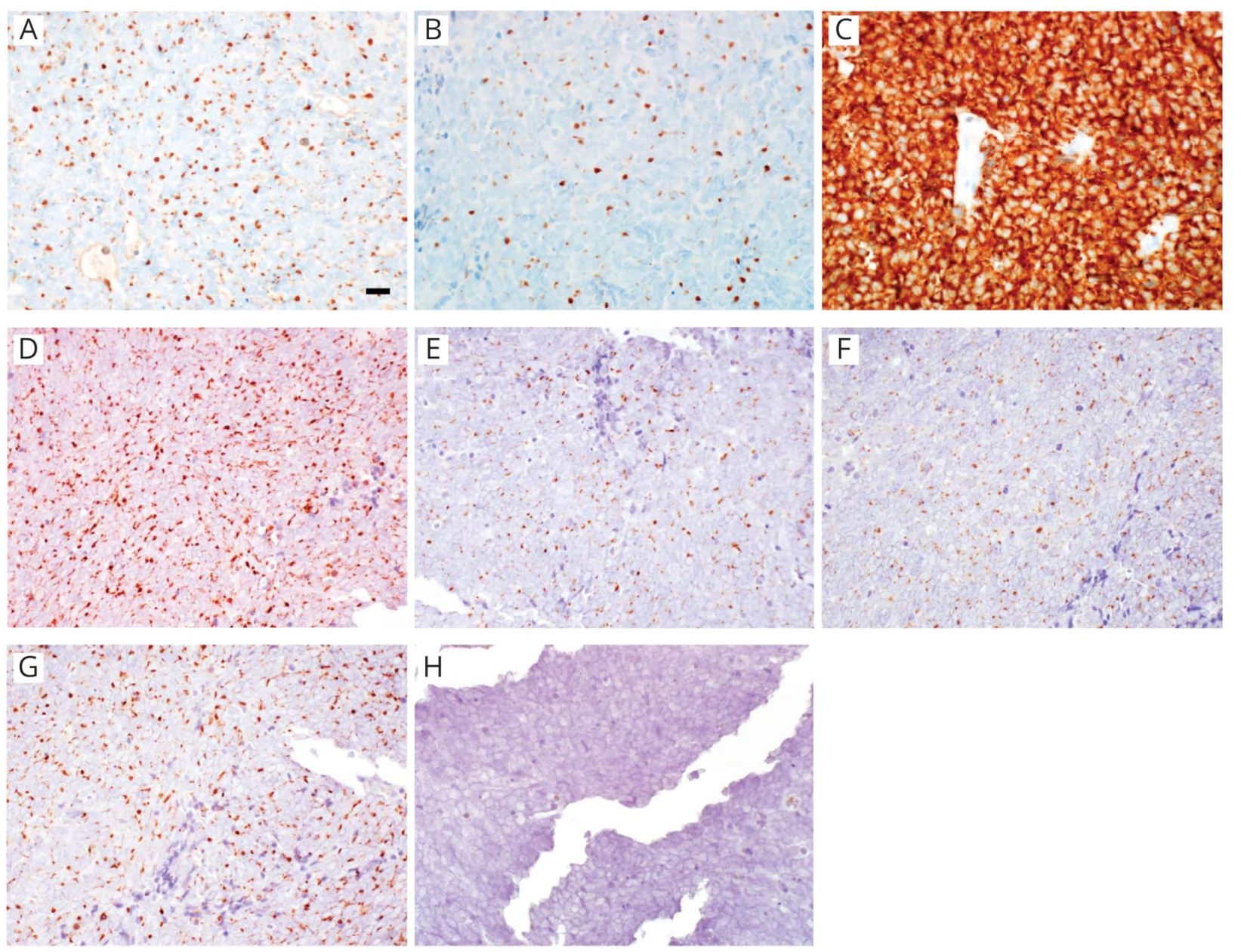

Metastatic tumor cells in lymph node of patient 8 (serum immunoglobulin G [lgG] positive for all NIFs except peripherin) show foci of cytokeratin immunoreactivities, AE1/AE3 (A) and CK20 (B), and universal synaptophysin immunoreactivity (C), consistent with Merkel cell carcinoma. Additional immunoreactivities demonstrated: a internexin (alN; D), neurofilament light chain (NfL; E), neurofilament medium chain (NfM; F), and neurofilament heavy chain ( $N f H$; $\mathrm{G})$; peripherin immunoreactivity was lacking $(\mathrm{H})$. Scale bar $=20 \mu \mathrm{m}$.

NIF specificity by detecting a profile of at least 2 , and usually $\geq 4$ NIF-IgGs, that always includes NfL-IgG. Subacute onset and rapidly progressive CNS disorders (usually cerebellar ataxia or encephalopathy or both) were encountered in affected patients. Consistent with the diffuse nervous system distribution of NIF antigens, occasional patients had coexisting myelopathy, cranial neuropathies, retinopathy, or peripheral neuropathy. Seventy-seven percent of those 21 patients had cancer, most commonly neuroendocrine lineage neoplasms (small cell, pancreatic, or Merkel cell carcinomas). This may be an underestimate given the short duration of follow-up available and limited data available on non-Mayo Clinic patients. Supportive findings for an autoimmune diagnosis in our $21 \mathrm{NfL}-\mathrm{IgG}$-positive patients included an inflammatory CSF in 7 of 10 with data available. Most had other clues to CNS inflammation in CSF or on MRI. Cancer specificity was supported by detection of NIF-IgG autoimmunity coexisting in a patient over 40 years of age with typical NMDAR encephalitis, but who had small cell carcinoma rather than the classically described ovarian teratoma. ${ }^{2}$
Antigen specificity was supported by the patient whose Merkel cell carcinoma had a NIF staining profile matching her NIF-IgG serologic profile. Affected patients, when treated with immunotherapy, generally improved, while those who went untreated died. Consistent with our experience, cerebellar degeneration has been reported as a paraneoplastic neurologic accompaniment of Merkel cell carcinoma., ${ }^{9,10}$ Another report demonstrated neurofilament triplet protein reactivity in sera from patients with paraneoplastic retinopathy accompanying small cell carcinoma. ${ }^{11,12}$ Our series also adds to the literature of paraneoplastic neurologic disorders arising during checkpoint inhibitor therapy for cancer. ${ }^{13}$

We also encountered 44 patients without NfL-IgG with less specific neurologic and cancer findings, which will require future study. Serologically, those patients were distinct from the NfLIgG-positive cases: their specimens usually produced a neurofilamentous pattern of staining on IFA resembling NfH-IgG (pattern 2) and had a more limited NIF-IgG profile by CBAs (just 1-2 antibodies positive, usually including $\mathrm{NfH}-\mathrm{IgG}$ ). 
While measurement of individual NIF proteins (such as phosphorylated $\mathrm{NfH}$ in serum and CSF of patients with ALS) has significance for neurodegenerative disease, ${ }^{14,15}$ measurements of individual NIF antibodies by ELISA, Western blot, or CBAs alone have unclear significance. ${ }^{6,8,16-22}$ Our experience of testing large numbers of controls yielded occasional positive results in serum in CBA only, among both healthy controls and patients with diverse disease states (such as MS, ALS, and CJD). In contrast, only 2 controls tested positive by both IFA and CBA. Both had small cell carcinoma without neurologic disease. Similarly, in our neurologic patients, diagnostic specificity for a paraneoplastic neurologic disorder required both positivity by screening with tissue IFA for pattern 1 and subsequent molecular confirmation by CBAs of an NIF-IgG profile that included NfL-IgG. At this early stage, evaluation of CSF in addition to serum appears to improve testing sensitivity.

$\alpha \mathrm{IN}, \mathrm{NfL}, \mathrm{NfM}$, and $\mathrm{NfH}$ are Class IV neuronal intermediate filaments widely expressed in mature central, peripheral, and autonomic neurons. ${ }^{23}$ Peripherin is a type III NIF expressed predominantly in the peripheral nervous system. ${ }^{24}$ NIFs support structure and functions such as transport and conduction of neuronal dendrites and axons throughout the nervous system. ${ }^{25-27} \mathrm{NfL}, \mathrm{NfM}$, and $\mathrm{NfH}$, so called because of their molecular weights, are obligate heteropolymers, known as neurofilament triplet proteins. As experienced with GFAP IgG, overexpression of a single GFP-tagged NIF in HEK-293 cells, without other NIF binding partners present, results in GFP-positive NIF inclusion bodies, rather than well-formed neurofilamentous tertiary structures. This did not hinder CBA interpretation. ${ }^{3,4}$ As is usually the case for paraneoplastic neurologic disorders, it is likely that NIF autoimmunity is cytotoxic $\mathrm{T}$ cell-mediated, and not antibody-mediated, given the exclusively cytoplasmic localization of NIF proteins. ${ }^{1}$

In normal skin, nerve fibers immunoreactive for NIFs are restricted to free nerve endings in the epidermis, dermal papilla, and Meissner corpuscles. ${ }^{28,29}$ In contrast, neurofilament triplet proteins and $\alpha \mathrm{IN}$ expression were diffusely expressed in metastatic cutaneous neuroendocrine (Merkel cell) neoplasm from patient 8 with cerebellar ataxia. The tumor's NIF immunoreactivity matched the patient's serum NIF-IgG profile (positive for 4 of 5, excluding peripherin). Consistent with the diversity of oncologic accompaniments encountered in our patients, NIF proteins are known to be expressed in lung carcinomas (both small cell and non-small-cell), neuroendocrine neoplasms, breast adenocarcinoma, sarcomas, and neuroblastomas. ${ }^{30-35}$ Though triton-insoluble, obtaining a NIF-enriched substrate for our Western blot was assured by solubilizing rat spinal cord in $8 \mathrm{M}$ urea. ${ }^{24}$

Neuronal precursor cells express the intermediate filaments nestin (type VI) and vimentin (type III) but their expression declines when these cells exit the cell cycle and differentiate into neurons. ${ }^{36}$ Tissue staining with commercial nestin and vimentin antibodies did not colocalize with our patient NIF-
IgGs. All intermediate filaments are composed of a central $\alpha$-helical rod domain flanked by $\mathrm{N}$ - (head) and C- (tail) terminals. ${ }^{37}$ In the rod domain, polypeptide dimers associate in parallel (known as coiled-coils). Differential amino acid sequences of nonconserved coiled-coil and C-terminal regions allow for diversity of structure and function of intermediate filaments. ${ }^{37,38}$ Consistent with a polyclonal response against NIF tertiary intermediate filament structures, our patients had diverse NIF-IgG profiles, and did not have a monoclonal reactivity with a highly conserved region common to all NIFs.

Patients with subacute onset of encephalopathy, ataxia, or myelopathy can undergo screening of serum and CSF by immunohistochemical techniques for both common and rare causes of paraneoplastic neurologic autoimmunity, including the pattern 1 of neurofilamentous staining we describe. Where CBAs confirm a profile of NIF-IgGs that includes positivity for NfL-IgG, a search for cancer (in particular those of neuroendocrine lineage) should be undertaken, and a trial of immunotherapy considered.

\section{Author contributions}

E.B.: study design, acquisition, analysis, and interpretation of data, drafting and critical revision of the manuscript. N.Z., T.J.K., S.R.H., Y.G., D.D., M.M., C.F.L., S.J.P., V.A.L.: data acquisition and analysis, critical revision of manuscript. E.E.B.: data interpretation and critical revision of manuscript. A.M.: study conception and design, acquisition, analysis, and interpretation of data, drafting and critical revision of the manuscript, study supervision.

\section{Acknowledgment}

The authors acknowledge the Mayo Clinic Center for Individualized Medicine and the Department of Laboratory Medicine and Pathology for provision of funding for this research; Vickie Mewhorter and Nancy Peters for technical support; Avi Gadoth, MD, for critical review of the figures; Masoud Majed, MD, for statistical support; and P. Pearse Morris, $\mathrm{MD}$, for assistance with radiologic data interpretation.

\section{Study funding}

No targeted funding reported.

\section{Disclosure}

E. Basal and N. Zalewski report no disclosures relevant to the manuscript. T. Kryzer is named inventor on a patent relating to AQP4 and MAP1B antibodies as markers of autoimmune neurologic disease. S. Hinson, Y. Guo, D. Dubey, and E. Benarroch report no disclosures relevant to the manuscript. C. Lucchinetti has received funding support from Biogen, Novartis, and Mallinkrodt and shares in royalties from marketing kits for detecting AQP4 autoantibody. S. Pittock holds patents that relate to functional AQP4/NMO-IgG assays and NMO-IgG as a cancer marker; has patents pending for MAP1B-IgG and Septin-5-IgG as markers of neurologic autoimmunity and paraneoplastic disorders; consulted for Alexion and Medimmune; and received research support 
from Grifols, Medimmune, and Alexion. All compensation for consulting activities is paid directly to Mayo Clinic. V. Lennon is named inventor on a patent relating to AQP4 as NMO antigen, and a pending patent related to $\mathrm{AQP} 4$ and cancer. Earnings to date from licensing this technology have exceeded the federal threshold for significant interest. A. McKeon has patents pending for MAP1B-IgG and Septin-5-IgG as markers of neurologic autoimmunity and paraneoplastic disorders; consulted for Grifols, Medimmune, and Euroimmun; and received research support from Medimmune and Euroimmun but has not received personal compensation. Go to Neurology.org/ $\mathrm{N}$ for full disclosures.

\section{Publication history}

\section{Received by Neurology April 3, 2018. Accepted in final form July} 23, 2018.

\section{References}

1. McKeon A, Pittock SJ. Paraneoplastic encephalomyelopathies: pathology and mechanisms. Acta Neuropathol 2011;122:381-400.

2. Dalmau J, Gleichman AJ, Hughes EG, et al. Anti-NMDA-receptor encephalitis: case series and analysis of the effects of antibodies. Lancet Neurol 2008;7:1091-1098.

3. Fang B, McKeon A, Hinson SR, et al. Autoimmune glial fibrillary acidic protein astrocytopathy: a novel meningoencephalomyelitis. JAMA Neurol 2016;73: 1297-1307.

4. Flanagan EP, Hinson SR, Lennon VA, et al. Glial fibrillary acidic protein immunoglobulin $\mathrm{G}$ as biomarker of autoimmune astrocytopathy: analysis of 102 patients. Ann Neurol 2017;81:298-309.

5. Braxton DB, Williams M, Kamali D, Chin S, Liem R, Latov N. Specificity of human anti-neurofilament autoantibodies. J Neuroimmunol 1989;21:193-203.

6. Fialova L, Bartos A, Svarcova J, Zimova D, Kotoucova J. Serum and cerebrospinal fluid heavy neurofilaments and antibodies against them in early multiple sclerosis. J Neuroimmunol 2013;259:81-87.

7. Fialova L, Svarcova J, Bartos A, et al. Cerebrospinal fluid and serum antibodies against neurofilaments in patients with amyotrophic lateral sclerosis. Eur J Neurol 2010;17: $562-566$.

8. Chamberlain JL, Pittock SJ, Oprescu AM, et al. Peripherin-IgG association with neurologic and endocrine autoimmunity. J Autoimmun 2010;34:469-477.

9. Iyer JG, Parvathaneni K, Bhatia S, et al. Paraneoplastic syndromes (PNS) associated with Merkel cell carcinoma (MCC): a case series of 8 patients highlighting different clinical manifestations. J Am Acad Dermatol 2016;75:541-547.

10. Balegno S, Ceroni M, Corato M, et al. Antibodies to cerebellar nerve fibres in two patients with paraneoplastic cerebellar ataxia. Anticancer Res 2005;25:3211-3214.

11. Kornguth SE, Kalinke T, Grunwald GB, Schutta H, Dahl D. Anti-neurofilament antibodies in the sera of patients with small cell carcinoma of the lung and with visua paraneoplastic syndrome. Cancer Res 1986;46:2588-2595.

12. Grunwald GB, Klein R, Simmonds MA, Kornguth SE. Autoimmune basis for visual paraneoplastic syndrome in patients with small-cell lung carcinoma. Lancet 1985;1. 658-661.

13. Kao JC, Liao B, Markovic SN, et al. Neurological complications associated with antiprogrammed death 1 (PD-1) antibodies. JAMA Neurol 2017;74:1216-1222.

14. Boylan KB, Glass JD, Crook JE, et al. Phosphorylated neurofilament heavy subunit (pNF-H) in peripheral blood and CSF as a potential prognostic biomarker in amyotrophic lateral sclerosis. J Neurol Neurosurg Psychiatry 2013;84: $467-472$.
15. Gendron TF, Daughrity LM, Heckman MG, et al. Phosphorylated neurofilamen heavy chain: a biomarker of survival for C9ORF72-associated amyotrophic latera sclerosis. Ann Neurol 2017;82:139-146.

16. Remaley A, Hortin GL. Protein analysis for diagnostic applications. In: Detrick B, Hamilton RG, Folds JD, eds. Manual of Molecular and Clinical Laboratory Immunology. Washington, DC: ASM Press; 2006:17-18.

17. Puentes F, Topping J, Kuhle J, et al. Immune reactivity to neurofilament proteins in the clinical staging of amyotrophic lateral sclerosis. J Neurol Neurosurg Psychiatry 2014;85:274-278.

18. Rajasalu T, Teesalu K, Janmey PA, Uibo R. Demonstration of natural autoantibodies against the neurofilament protein alpha-internexin in sera of patients with endocrine autoimmunity and healthy individuals. Immunol Lett 2004;94:153-160.

19. Fialova L, Bartos A, Svarcova J, Zimova D, Kotoucova J, Malbohan I. Serum and cerebrospinal fluid light neurofilaments and antibodies against them in clinically isolated syndrome and multiple sclerosis. J Neuroimmunol 2013;262:113-120.

20. Bahmanyar S, Liem RK, Griffin JW, Gajdusek DC. Characterization of antineurofilament autoantibodies in Creutzfeldt-Jakob disease. J Neuropathol Exp Neurol 1984;43:369-375.

21. Toh BH, Gibbs CJ Jr, Gajdusek DC, Goudsmit J, Dahl D. The 200- and 150-kDa neurofilament proteins react with IgG autoantibodies from patients with kuru, Creutzfeldt-Jakob disease, and other neurologic diseases. Proc Natl Acad Sci USA $1985 ; 82: 3485-3489$.

22. Lu XY, Chen XX, Huang LD, Zhu CQ Gu YY, Ye S. Anti-alpha-internexin autoantibody from neuropsychiatric lupus induce cognitive damage via inhibiting axonal elongation and promote neuron apoptosis. PLoS One 2010;5:e11124.

23. Trojanowski JQ, Walkenstein N, Lee VM. Expression of neurofilament subunits in neurons of the central and peripheral nervous system: an immunohistochemical study with monoclonal antibodies. J Neurosci 1986;6:650-660.

24. Leung CL, Liem RK. Isolation of intermediate filaments. Curr Protoc Cell Biol 2006, Ch 3:Unit 3.23.

25. Yan Y, Jensen K, Brown A. The polypeptide composition of moving and stationary neurofilaments in cultured sympathetic neurons. Cell Motil Cytoskeleton 2007;64:299-309.

26. Kirkcaldie MTK, Dwyer ST. The third wave: intermediate filaments in the maturing nervous system. Mol Cell Neurosci 2017;84:68-76

27. Yuan A, Nixon RA. Specialized roles of neurofilament proteins in synapses: relevance to neuropsychiatric disorders. Brain Res Bull 2016;126:334-346.

28. Dalsgaard CJ, Bjorklund H, Jonsson CE, Hermansson A, Dahl D. Distribution of neurofilament-immunoreactive nerve fibers in human skin. Histochemistry 1984;81. 111-114.

29. Kanitakis J, Bourchany D, Faure M, Claudy A. Expression of the intermediate filament peripherin in skin tumors. Eur J Dermatol 1998;8:339-342.

30. Liu B, Tang LH, Liu Z, et al. alpha-Internexin: a novel biomarker for pancreatic neuroendocrine tumor aggressiveness. J Clin Endocrinol Metab 2014;99:E786-E795.

31. Willoughby V, Sonawala A, Werlang-Perurena A, Donner LR. A comparative immunohistochemical analysis of small round cell tumors of childhood: utility of peripherin and alpha-internexin as markers for neuroblastomas. Appl Immunohistochem Mol Morphol 2008;16:344-348.

32. $\mathrm{Li} \mathrm{XQ}, \mathrm{Li} \mathrm{L}$, Xiao CH, Feng YM. NEFL mRNA expression level is a prognostic facto for early-stage breast cancer patients. PLoS One 2012;7:e31146.

33. Kiriakogiani-Psaropoulou P, Malamou-Mitsi V, Martinopoulou U, et al. The value of neuroendocrine markers in non-small cell lung cancer: a comparative immunohistopathologic study. Lung Cancer 1994;11:353-364.

34. Molenaar WM, Muntinghe FL. Expression of neural cell adhesion molecules and neurofilament protein isoforms in Ewing's sarcoma of bone and soft tissue sarcomas other than rhabdomyosarcoma. Hum Pathol 1999;30:1207-1212.

35. Molenaar WM, Muntinghe FL. Expression of neural cell adhesion molecules and neurofilament protein isoforms in skeletal muscle tumors. Hum Pathol 1998;29:1290-1293.

36. Nixon RA, Shea TB. Dynamics of neuronal intermediate filaments: a developmental perspective. Cell Motil Cytoskeleton 1992;22:81-91.

37. Herrmann H, Bar H, Kreplak L, Strelkov SV, Aebi U. Intermediate filaments: from cell architecture to nanomechanics. Nat Rev Mol Cell Biol 2007;8:562-573.

38. Harris J, Ayyub C, Shaw G. A molecular dissection of the carboxyterminal tails of the major neurofilament subunits NF-M and NF-H. J Neurosci Res 1991;30:47-62. 


\title{
Neurology
}

\author{
Paraneoplastic neuronal intermediate filament autoimmunity \\ Eati Basal, Nicholas Zalewski, Thomas J. Kryzer, et al. \\ Neurology 2018;91;e1677-e1689 Published Online before print October 3, 2018 \\ DOI 10.1212/WNL.0000000000006435
}

This information is current as of October 3, 2018

Updated Information \&
Services

References

Citations

Subspecialty Collections

Permissions \& Licensing

Reprints including high resolution figures, can be found at: http://n.neurology.org/content/91/18/e1677.full

This article cites 36 articles, 6 of which you can access for free at: http://n.neurology.org/content/91/18/e1677.full\#ref-list-1

This article has been cited by 3 HighWire-hosted articles: http://n.neurology.org/content/91/18/e1677.full\#\#otherarticles

This article, along with others on similar topics, appears in the following collection(s):

Autoimmune diseases

http://n.neurology.org/cgi/collection/autoimmune_diseases

Gait disorders/ataxia

http://n.neurology.org/cgi/collection/gait_disorders_ataxia

Paraneoplastic syndrome

http://n.neurology.org/cgi/collection/paraneoplastic_syndrome

Information about reproducing this article in parts (figures,tables) or in its entirety can be found online at:

http://www.neurology.org/about/about_the_journal\#permissions

Information about ordering reprints can be found online:

http://n.neurology.org/subscribers/advertise

Neurology ${ }^{\circledR}$ is the official journal of the American Academy of Neurology. Published continuously since 1951, it is now a weekly with 48 issues per year. Copyright Copyright ( 2018 The Author(s). Published by Wolters Kluwer Health, Inc. on behalf of the American Academy of Neurology.. All rights reserved. Print ISSN: 0028-3878. Online ISSN: 1526-632X.

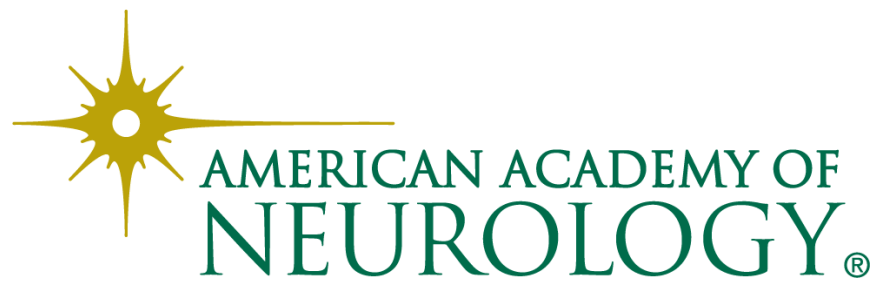

